\title{
HOW SUSTAINABLE IS YOUR FOOD?
}

MODERN FOOD PRODUCTION AND TRADE HAVE COUNTLESS IMPACTS ON THE ENVIRONMENT. SUSTAINABLE FOOD SYSTEMS ARE THEREFORE INDISPENSABLE FOR FUTURE FOOD SECURITY, BUT HOW CAN WE ASSESS THE ENVIRONMENTAL SUSTAINABILITY OF FOOD? DR CAROLE DALIN, A SUSTAINABILITY RESEARCHER AT UNIVERSITY COLLEGE LONDON IN THE UK, IS DEVELOPING INTEGRATED ENVIRONMENTAL INDICATORS TO TRACK PROGRESS TOWARDS SUSTAINABLE AGRICULTURE

\section{TALK LIKE A SUSTAINABLE FOOD SYSTEMS RESEARCHER}

BIODIVERSITY - the variety of species in an environment, comprising all forms of life including plants, animals, fungi and bacteria

CASH CROP - an agricultural crop grown to sell for profit

FOOD SECURITY - the availability of sufficient food for the whole of the world's population

FOOD SYSTEM - all activities and infrastructure involved in producing food for a population, including planting, growing, harvesting, livestock rearing, processing, packaging, transportation, marketing,

Agriculture is essential. Without farms and farmers, we would have no food to eat. And yet the way we grow crops and raise animals has a huge impact on the environment, as does the process of transporting food from the farm to your plate. Not only that, but global population growth means that the world will have to produce even more food in the future.

"If current diets remain, it is projected that food production will need to almost double by 2050," says Dr Carole Dalin, Associate Professor in the Institute for Sustainable Resources at University College London. "If current agricultural practices also remain, this could lead to distribution, consumption and disposal

GREENHOUSE GAS - an atmospheric gas that absorbs and re-emits thermal infrared radiation, insulating the Earth so causing the planet to warm up. Important greenhouse gases emitted by human activities include carbon dioxide, methane and nitrous oxide

MONOCULTURE - the cultivation of a single crop

SUSTAINABILITY - using resources without depleting them so that future users can continue to benefit from them

catastrophic consequences for water resources, climate change and biodiversity."

Moving towards sustainable agriculture is therefore essential to ensuring that everyone has enough food to eat in the future, while also ensuring everyone has access to water, fighting against climate change, and protecting against biodiversity loss. To help achieve this, Carole is developing indicators that measure how environmentally friendly agricultural activities and products really are. Her work makes it possible to track our progress towards sustainable agriculture and make better choices in our food production and consumption.
HOW DOES AGRICULTURE AFFECT THE ENVIRONMENT?

Agriculture requires vast quantities of water to grow crops and raise livestock. Globally, 70\% of the water we extract from the environment is used to irrigate crops and $90 \%$ of all the water we consume is used for agriculture. This overuse of water is drying up rivers and depleting underground water reserves in many parts of the world.

Agricultural practices also pollute water sources and reduce air quality. Chemical fertilisers, pesticides and herbicides are added to crops to increase productivity and decrease pests and weeds, and these are washed into rivers. Livestock produce vast quantities of manure which also contributes to water and air pollution.

Greenhouse gases emitted by agricultural practices are significant contributors to climate change. Nitrous oxide, a potent greenhouse gas, is a by-product of fertilisers, and agriculture accounts for over $50 \%$ of human-induced nitrous oxide emissions. Cattle produce huge amounts of methane, another powerful greenhouse gas, and are responsible for over $40 \%$ of human-induced methane emissions. It will be difficult, if not impossible, to reduce greenhouse gas emissions from agriculture to zero.

Agriculture is also reducing global biodiversity, not only through the use of pesticides and herbicides, which kill insects and plants, but also 
due to the clearance of land to create space for farming. About $40 \%$ of the world's ice-free land is pasture and cropland. Humans occupy so much land that habitats for wild species have shrunk and the numbers both of individual animals and of existing species have declined steeply in recent decades. As all species in an ecosystem are interconnected through complex relationships, biodiversity loss is dangerous; the reduction of just a few species may lead to the collapse of a whole ecosystem.

The global trade of food also has an impact on its sustainability, as $10-20 \%$ of food is exported from where it is produced to other countries. Some foods, such as tropical fruits, coffee and cocoa, are grown in only a few regions and are then shipped around the world, resulting in greenhouse gas emissions from transportation. Food trade provides economic opportunities in many developing countries, but often at the detriment of local ecosystems. Huge swathes of rainforests are cut down every day in southeast Asia to grow palm oil and in the Amazon to grow soybean and raise cattle. This intensive cultivation of cash crops not only destroys the original ecosystems but results in monocultures with very low biodiversity.

The industrialised, out-of-sight production and trade of food often keeps consumers in the dark about the environmental consequences of how the food on their plates has arrived there.

\section{QUANTIFYING THE ENVIRONMENTAL IMPACT OF FOOD PRODUCTION}

\section{Carole's research project, Developing}

Integrated Environmental Indicators for Sustainable Global Food Production and Trade (FOODIES), is about developing indicators that distil multiple pieces of information into one metric to measure the environmental impact of an agricultural activity. "Sustainability is about whether future users will be able to continue to obtain the same benefits," Carole explains. "To determine environmental sustainability, we look at whether different agricultural activities use more resources than are naturally renewed and whether the systems supporting the agriculture (climate and biodiversity) are negatively affected."

\section{Carole and her team use satellite data to} identify regions of cropland and irrigation. They use data from national surveys, such as reported quantities of crop production or fertiliser use, to assess the agricultural productivity of different areas. And they examine accounts of imports and exports to determine the nature of global agricultural trade. They then combine these data and use models of environmental processes to establish the sustainability of different agricultural practices, products and regions. "We have selected four key environmental pressures from agriculture - water use, greenhouse gas emissions, fertiliser use and land use," explains Carole. "I have developed sustainability indicators for each, and we are now working on integrating these into a composite indicator, to compare the sustainability 'performance' across different regions and products." These sustainability indicators developed by the FOODIES project will make it possible to quantify how sustainable food systems are and track our progress as we try to make them more environmentally friendly.

\section{SUSTAINABLE AGRICULTURAL PRACTICES}

Many changes need to be implemented to improve the sustainability of agriculture. Increased agricultural efficiency will mean fewer resources are needed to produce the same outputs. Chemical fertiliser use can be reduced by testing soil nutrient levels and only applying fertilisers in calculated amounts, thereby reducing nitrous oxide emissions. Agroforestry (growing trees together with agricultural crops) fights climate change by sequestering carbon in the trees and boosts biodiversity by providing habitats for tree-living species. And cultivating crops that are more suitable for local soils and climates will help to save water and support biodiversity.

Carole's research teases out the impact of each of these reforms. "We build models of food systems covering key relationships (physical and socio-economic) and then use these models to test the impact of a scenario where one or more changes are implemented," she says. Carole's models and sustainability indicators allow quantitative comparisons of different potential future food systems to be conducted.

\section{WHAT CAN WE DO AS INDIVIDUALS?}

Carole's research is immensely practical and impactful. Her results can help government policy-makers, farmers and consumers make better decisions about producing and buying food. "I hope my research identifies priority targets, helps design sustainable diets, highlights that both the location and the method of producing food matter (local food is not always more sustainable!) and encourages coordination between trade partners to ensure sustainability," she says.

But individuals also have a role to play in ensuring that food production is sustainable. The attitudes and practices of both food producers and consumers will have to change if we want to avoid climate catastrophe and biodiversity

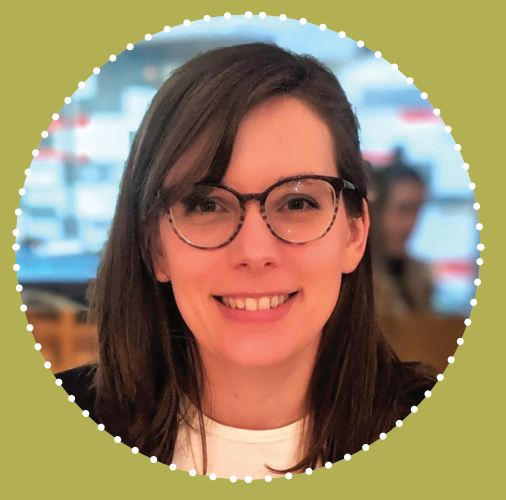

DR CAROLE DALIN

Associate Professor, Institute for Sustainable Resources, University College London, UK

.........

FIELD OF RESEARCH

Sustainable Food Systems $\ldots \ldots \ldots \ldots$

\section{RESEARCH PROJECT}

Developing integrated indicators to measure the environmental impact of food production activities, products and regions

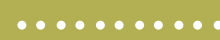

FUNDER

Natural Environmental Research Council (Grant NE/N01524X/1)

collapse and still feed the people of the future. Methane emissions from livestock would be reduced if we cut down our consumption of milk and red meat, in favour of plant-based proteins. Oat milk is generally the most environmentally friendly vegan milk because almond milk is very water-intensive and soy milk is linked to deforestation. The majority of global crops are grown to feed animals rather than humans, so switching to a plant-based diet will also mean that agricultural land is used more efficiently. As so many resources are used to produce food, avoid food waste. Food in landfill produces greenhouse gas emissions, so if you must dispose of food, compost it if you can.

Try to buy food that is not packed in plastic and recycle all packaging waste if possible. To reduce the emissions associated with transportation, try to buy local produce rather than food from the other side of the world. But remember that the method of production also has an impact, and locally produced food is not always better for the environment!

Stay hopeful - we can all contribute to a sustainable future, where enough food is produced for everyone while still conserving the environment. 


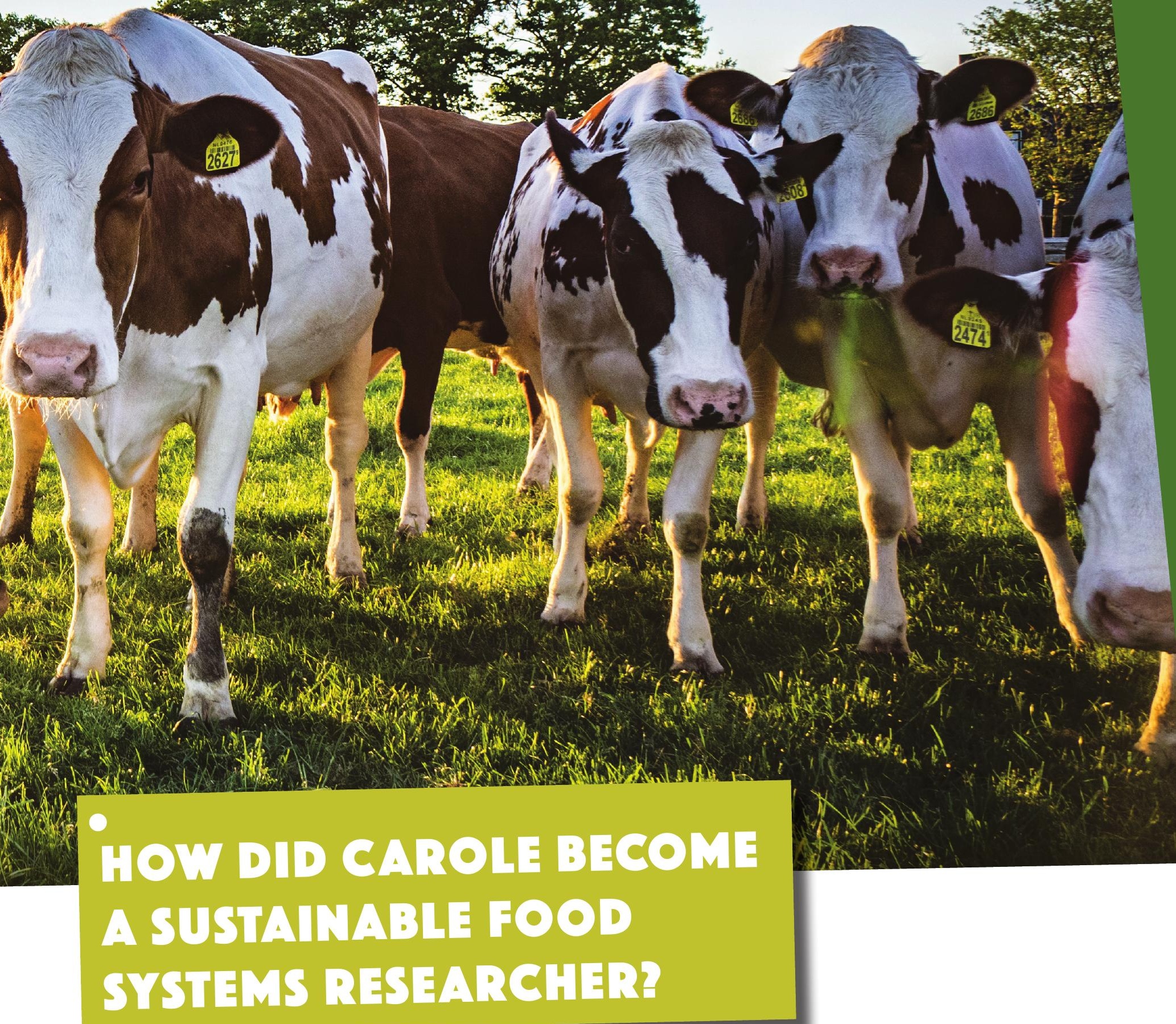

AS THE LEADER OF THE FOODIES PROJECT, ARE YOU A 'FOODIE' PERSON YOURSELF?

Yes! I choose this acronym because it names the main theme: food, but the "FOODIES" acronym is also a sort of joking reference to myself, as leader of the project. I love making recipes and trying different foods at restaurants, too. I discovered vegetarian food during my PhD from my Indian roommates - eating less meat is much better for sustainability. But I am from France, so I still probably eat too much cheese than what is recommended for health and the environment - old habits die hard!

\section{WHAT MOTIVATED YOU TO STUDY} SUSTAINABLE FOOD SYSTEMS?

I have always been interested in human lives, and in how they depend on - and interact with - the natural environment. I first focused on climate change and energy after high school, but was then drawn to the issue of water resources. Studying water use, I discovered that agriculture is by far the most waterintensive activity, and this is how I ended up studying sustainable food.

\section{WHAT HAVE YOU MOST ENJOYED} ABOUT YOUR CAREER SO FAR?

After my undergraduate degree in France, I had the opportunity to study abroad in the USA for a master's degree in environmental engineering and water resources. I stayed on for a PhD, and then continued working abroad, moving to the UK. I have met so many different people with their own cultures, interests and insights. This has brought huge benefits to both my professional career and my personal life.

WHAT PERSONAL QUALITIES HAVE MADE YOU SUCCESSFUL AS A RESEARCHER?
Curiosity to find the truth - I like to search for the evidence behind a statement. Also, the ability to tease out the key elements in a complex picture helped me a lot. Being able to write well and concisely are also key skills for researchers.

HOW DO YOU SWITCH OFF FROM WORK?

I try to stop work at a given time each day. Once I have finished, I avoid reading emails on my phone. Instead, I go outside, exercise, turn music on... or I cook!

WHAT FACT SHOULD EVERYONE KNOW ABOUT SUSTAINABLE FOOD SYSTEMS?

Food production alone accounts for about a third of the ecological impact of all our activities - we can all make a big difference by making small changes in our food habits. 